\title{
The Prairie Historians and the Foundations of Midwestern History
}

\author{
JON K. LAUCK
}

From the earliest days of the American republic, New England received considerable attention from historians. The American South also produced many men of letters and later historians dedicated to understanding its traditions and peculiar institution. Yet the American "West," a constantly shifting region in the American imagination, was given short shrift in the main channels of nineteenth-century American historiography. By the beginning of the twentieth century, however, historians in the Midwest were beginning to assert themselves in the form of published works, increasingly active state historical societies, and new scholarly journals. From the late nineteenth century extending several decades into the twentieth, a cadre of midwestern historians busily chronicled their region. These "Prairie Historians," as I call them, made a substantial contribution to the historical profession and wrote the foundational histories of the prairie Midwest, but they are seldom thought of today. The history profession is still interested in New England and the American South; in recent decades, the American Far West has also developed into a major field of study that dwarfs the midwestern history enterprise. Even the few historians who now study the Midwest pay little attention to the Prairie Historians. That once proud band, however, devoted much of their lives to

THE ANNALS OF IOWA 71 (Spring 2012). (C) The State Historical Society of Iowa, 2012. 
the region, and the impressive body of work they left behind deserves to be remembered both on its own terms and as a monument to a once energetic cadre of scholars.

Grouping intellectuals, including the Prairie Historians, is always difficult. The Romantics, the Southern Agrarians, the New York Intellectuals, and the British Marxist historians, for example, all defy tidy categories, yet the thrust of their work and attitudes have at times been successfully captured by their chroniclers. The main currents of their thought and their collective "mind" can be mapped and described while giving due consideration to the nuances, intricacies, and contradictions within their work. Not all of the characteristics that unite the Prairie Historians apply to all of them all of the time, of course, but the unifying elements are reasonably strong. Many of the Prairie Historians were born in the prairie Midwest, often on midwestern farms, and were inclined to study their home region. They supported local history, state historical societies, and regional journals focused on the prairie Midwest. They admired Frederick Jackson Turner, studied the political and economic development of the Midwest, and embraced democracy as a central theme in their histories; more particularly, they focused on law, farming, Populism, land and geography, and social history. Their collective effort yielded a raft of major books and several Pulitzer prizes.

ANY DISCUSSION of the foundations of midwestern history must begin with Frederick Jackson Turner of Wisconsin. When Turner began his study of history in the 1880s, the writing of history, Curtis Nettels noted, "was almost a monopoly of the Atlantic seaboard." 1 Breaking with eastern historians, who saw midwestern culture and institutions as derivative and imitative and who largely ignored happenings beyond the Hudson River, Turner argued that midwestern settlers advanced American democratic practices on the frontier. His work begat a tradition of

1. Curtis P. Nettels, "History Out of Wisconsin," Wisconsin Magazine of History 39 (1955-56), 116. On Turner and midwestern history, see David S. Brown, Beyond the Frontier: The Midwestern Voice in American Historical Writing (Chicago, 2009), 25-50; and Jon K. Lauck, “The 'Interior Tradition' in American History: A Review Essay,” Annals of Iowa 69 (2010), 82-93. 
historical writing about and from the Midwest. Turner said that he saw his famous frontier thesis as "a protest against eastern neglect." 2 The Prairie Historians took cues from Turner and developed a pattern of thought and a network of personalities, affiliations, and institutions that congealed into an early twentiethcentury movement to advance the cause of studying the history of the Midwest.

In keeping with Turner's call for greater attention to the Midwest, the Prairie Historians sought an outlet for the region's history. The secretary of the Nebraska State Historical Society, Clarence Paine, a Minnesotan living in Iowa who caught the eye of former Nebraska territorial governor and U.S. Secretary of Agriculture J. Sterling Morton, led the charge. ${ }^{3}$ In 1907 Paine convened a meeting in Lincoln of representatives of midwestern historical societies who debated a constitution for a new organization called the Mississippi Valley Historical Association (MVHA). ${ }^{4}$ Because Secretary Morton gave Paine his platform, he is generally considered the "genuine spiritual godfather" of the MVHA. ${ }^{5}$ The eastern-dominated American Historical Association (AHA) opposed the new organization, but the MVHA's

2. Michael C. Steiner, “The Significance of Turner's Sectional Thesis," Western Historical Quarterly (hereafter WHQ) 10 (1979), 443 (quoting Turner).

3. Clarence Paine was from Eden Valley Township, Minnesota, had worked on a farm and in a lumber camp, founded a business college in Iowa, and become interested in promoting the efforts of the Iowa Historical Department when Morton tapped him to work on a large-scale history of Nebraska. James L. Sellers, "Before We Were Members - The MVHA," Mississippi Valley Historical Review (hereafter MVHR) 40 (1953), 6; Benjamin F. Shambaugh, "The Sixteenth Annual Meeting of the Mississippi Valley Historical Association," MVHR 10 (1923), 112.

4. Although Turner never served as president of the MVHA, it was "quintessentially the organization of Frederick Jackson Turner, who dominated its proceedings and consciousness for many years." Stanley N. Katz, "The Rise of a Modern and Democratic Learned Society," in Richard S. Kirkendall, ed., The Organization of American Historians and the Writing and Teaching of American History (New York, 2011), 14. Michael Kammen notes that "Turner's influence [on the MVHA] was ubiquitous and persistent" and concludes, based on a review of the published work of the MVHA, that "no other figure dominates, personally and intellectually, as much as Turner." Michael Kammen, "The Mississippi Valley Historical Association, 1907-1952," in Kirkendall, ed., The $\mathrm{OAH}, 22$.

5. Sellers, "Before We Were Members," 6. On Morton, see James C. Olson, J. Sterling Morton (Lincoln, NE, 1942). 


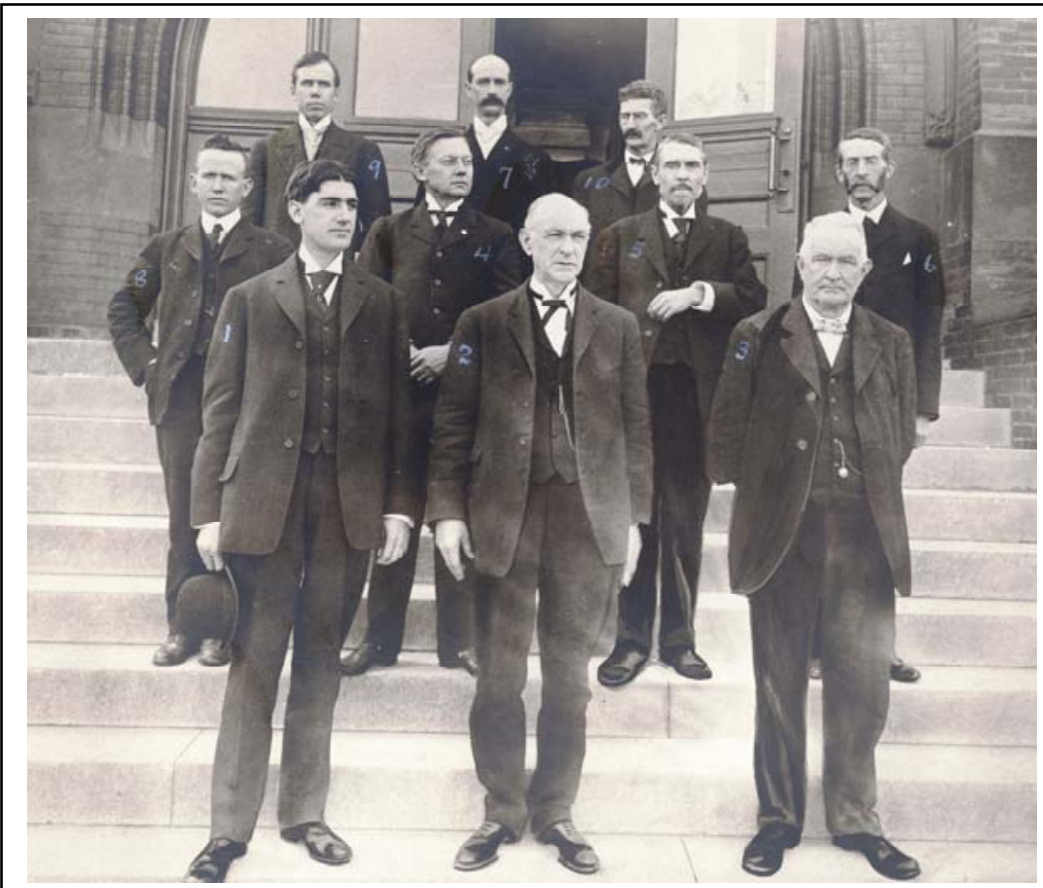

In 1907 historians from around the Midwest organized the Mississippi Valley Historical Association at a meeting in Lincoln, Nebraska: 1 (see numbers on sleeves)-Benjamin F. Shambaugh, 2-Francis A. Sampson, 3George W. Martin, 4-Edgar A. Harlan, 5-Warren Upham, 6-William S. Bell, 7-Clarence S. Paine, 8-Edwin Maxey, 9-William E. Hannan, 10Elmer E. Blackman. Photo from Nebraska State Historical Society.

leaders refused to compromise their plans, repeatedly noting that the AHA devalued the history of their region. ${ }^{6}$

6. Midwesterners had "long resented what they saw as control of the profession by a northeastern (and especially New England) elite." Peter Novick, That Noble Dream: The "Objectivity Question" and the American Historical Profession (New York, 1988), 181. Historians complained of the "difficulty of getting articles on Western history accepted by journals edited in the East." Nettels, "History Out of Wisconsin," 115. On the hostility to western history at Yale, see Jon Lauck, "The Old Roots of the New History: Howard Lamar and the Intellectual Origins of Dakota Territory," WHQ 39 (2008), 262. On the hostility to western history at Harvard, see Frederick Merk to Milo Quaife, 10/15/1916, General Administrative Correspondence of WHS, 1900-2000, Wisconsin Historical Society, Madison, WI. On the friction between midwestern historians and easterners, see Kammen, "Mississippi Valley Historical Association, 1907$1952, " 18-20$. 
At the AHA meeting in Madison, Wisconsin, in December 1907, the leaders of the new MVHA adopted a constitution, declaring that the "object of the Association shall be to promote historical study and research and to secure cooperation between the historical societies and the departments of history of the Mississippi Valley." 7 The new organization set its first meeting for Lake Minnetonka, Minnesota, in June 1908. The AHA continued to refuse to work with the MVHA, so the budding organization subsequently met on its own in St. Louis and Iowa City and again in Lincoln. ${ }^{8}$ Throughout the next decade, despite midwesterners' attempts to assert a stronger voice, the "domination" of the profession by easterners "continued unabated, as did resentment in the outback." ${ }^{9}$ In 1915 the MVHA president signed a circular on MVHA letterhead lending support to "reformers" within the AHA who wanted to break the eastern clique that dominated that organization. ${ }^{10}$ The MVHA found an audience by drawing on this midwestern regionalist impulse

7. Sellers, "Before We Were Members," 8; Nettels, "History Out of Wisconsin," 115; Vernon Carstensen to Merle Curti, 7/1/1951, folder 18, box 8, Merle Curti Papers, Wisconsin Historical Society, Madison, WI.

8. John R. Wunder, "The Founding Years of the OAH," OAH Newsletter 34 (November 2006), www.oah.org/pubs/nl/2006nov/wunder.html; Novick, That Noble Dream, 182; Ian Tyrrell, "Public at the Creation: Place, Memory, and Historical Practice in the Mississippi Valley Historical Association, 1907-1950," Journal of American History (hereafter JAH) 94 (2007), 27.

9. Novick, That Noble Dream, 183.

10. Some MVHA leaders objected to the president, Dunbar Rowland, sending his statement on MVHA letterhead without getting the MVHA's approval, and Professor Claude H. Van Tyne of the University of Michigan resigned from the board of editors in protest. See numerous letters in MVHA Correspondence, vol. 2, Alvord Papers, State Historical Society of Missouri, Columbia, MO. Clarence Alvord generally tried to keep the MVHA out of the AHA "fiasco." Alvord to Van Tyne, 10/18/1915, vol. 2, MVHA correspondence, Alvord Papers. Shambaugh and Paxson opposed being drawn into the AHA imbroglio. Frederic Paxson to Alvord, 11/12/1915, and Benjamin Shambaugh to Alvord, 11/13/1915, MVHA correspondence, vol. 2, Alvord Papers. The MVHA's neutrality in the AHA battle stemmed in part from the fact that Turner, then at Harvard, was being attacked as part of the AHA "oligarchy." R. R. Palmer, "The American Historical Association in 1970," American Historical Review (hereafter AHR) 76 (1971), 5. Turner sought moderate reforms within the AHA. Ray Allen Billington, “Tempest in Clio's Teapot: The American Historical Association Rebellion of 1915," AHR 78 (1973), 354. See also Allan G. Bogue, Frederick Jackson Turner: Strange Roads Going Down (Norman, OK, 1998), 305-19. 
and grew from its seven original members in 1907 to 840 members by 1923.11

AMONG THE FOUNDERS of the MVHA were Clarence W. Alvord of the University of Illinois and Benjamin F. Shambaugh of the University of Iowa. Alvord took over the presidency of the MVHA during its first year when the original president, from Alabama, complained about the first meeting being held too far north in Minnesota and lost interest. ${ }^{12}$ Alvord was a strong proponent of maintaining the MVHA's regional distinctiveness and fought the cooptation efforts of the AHA, which, he argued, was too focused on the East and which, he noted, was mounting "a good deal of opposition" to the new MVHA. ${ }^{13} \mathrm{Al}-$ vord thought that the "development of the Northeast, particularly of New England, [had] usurped too prominent a place in the annals of America" and that eastern historians were prone to erroneous "blunders" about western history. ${ }^{14}$ In addition to leading the MVHA, Alvord also collected, edited, and published many records from early Illinois history, served as the editor of the Illinois Historical Collections, led the Illinois Historical Survey, and wrote books about the history of Illinois. ${ }^{15}$ Frederic Logan Paxson, who sympathized with the effort to break the "northern tide-water point of view," wrote in the 1920s that the "sound scholarship of Alvord and his host of associates has

11. Benjamin F. Shambaugh, "The Sixteenth Annual Meeting of the Mississippi Valley Historical Association," MVHR 10 (1923), 113; Kammen, “The Mississippi Valley Historical Association, 1907-1952," 18-20.

12. Wunder, "The Founding Years of the OAH."

13. Alvord to Dunbar Rowland, 10/19/1915, MVHA correspondence, vol. 2, Alvord Papers; Solon J. Buck, "Clarence Walworth Alvord, Historian," MVHR 15 (1928), 314; Wunder, "The Founding Years of the OAH"; Theodore C. Blegen, "Our Widening Province," MVHR 31 (1944), 5; James L. Sellers, "The Semicentennial of the Mississippi Valley Historical Association," MVHR 44 (1957), 498 ("good deal" quote). For more on the growth of the MVHA, see Tyrrell, "Public at the Creation," 19-46.

14. Clarence W. Alvord, "The Study and Writing of History in the Mississippi Valley," in Benjamin F. Shambaugh, ed., Proceedings of the Mississippi Valley Historical Association, vol. 1, 1907-1908 (Cedar Rapids, 1909), 101, 104.

15. Buck, "Clarence Walworth Alvord," 309-14. See also Dixon Ryan Fox, “State History II," Political Science Quarterly 37 (1922), 99-118. 
cleared the ground" for the development of western history. ${ }^{16}$

Shambaugh was a native Iowan born on a farm in Clinton County and, although formally a political scientist, served as the superintendent and editor of the publications of the State Historical Society of Iowa in Iowa City from 1907 to $1940 .{ }^{17}$ In keeping with the anti-eastern posture, populist spirit, and public orientation of the MVHA, Shambaugh emphasized the value of reaching a general audience, bringing high school teachers into the association, and studying subjects such as constitutional development to generate a "commonwealth" history usable by the citizenry. ${ }^{18}$ Shambaugh praised the MVHA for the "absence of that smugness which too often finds its way into historical societies." 19

Shambaugh aided the budding MVHA by editing its Proceedings and publishing its conference papers until Alvord secured funding from the University of Illinois for the permanent publication of the association's new journal, the Mississippi Valley Historical Review (MVHR). Alvord became the first editor of the MVHR and served until 1923.20 The MVHR was "primarily interested in the history of the Mississippi Valley" but was open to other articles bearing on the development of the region. Alvord promised that the MVHR would be "more closely connected with

16. Frederic Logan Paxson, History of the American Frontier, 1763-1893 (Boston, 1924), preface, $111 n$.

17. By 1934, Shambaugh had already published 720 works. Julian P. Boyd, "State and Local Historical Societies in the United States," AHR 40 (1934), 31. Shambaugh received his B.A. and M.A. from the University of Iowa and his Ph.D. from the Wharton School. He transformed the Iowa Historical Record into the more scholarly Iowa Journal of History and Politics in 1903. Wunder, "The Founding Years of the OAH," n. 13; William D. Aeschbacher, "The Mississippi Valley Historical Association, 1907-1965," JAH 54 (1967), 348; Alan M. Schroder, "Benjamin F. Shambaugh," in John R. Wunder, ed., Historians of the American Frontier (Westport, CT, 1988), 611-12.

18. Wunder, "The Founding Years of the OAH"; David Thelen, "Of Audiences, Borderlands, and Comparisons: Toward the Internationalization of American History," JAH 79 (1992), 436; Rebecca Conard, Benjamin Shambaugh and the Intellectual Foundations of Public History (Iowa City, 2002), 11; Benjamin F. Shambaugh, The Constitutions of Iowa (Iowa City, 1934). See also "Benjamin F. Shambaugh," Palimpsest 21 (1940), 133-39.

19. Shambaugh, "Sixteenth Annual Meeting of the MVHA," 112.

20. See letters discussing the creation of the MVHR, 1913-14, MVHA correspondence, vol. 1, Alvord Papers; Buck, "Clarence Walworth Alvord," 315. 
the historical societies in the country than the American Historical Review is." Shambaugh said that there was "no reason why readability, accuracy, and scholarship cannot be combined in the same article." Alvord agreed. He sought to publish articles that were "clear" and "self-explanitory" [sic] and that would serve the "great public" instead of being limited to "specialists." Such a policy, he said, was "not contrary to scientific work." Thus the MVHR became the "organ of the Westerners." 21

The new MVHA, midwestern-oriented and ably led by Alvord and Shambaugh, was aided by other members of the founding generation of Prairie Historians. Following Alvord's leadership at the University of Illinois was Theodore Calvin Pease. Born in Cassopolis, Michigan, he earned a B.A. from Illinois and a Ph.D. from the University of Chicago and went on to author detailed histories of Illinois and assist the state's historical society. ${ }^{22}$ Following Shambaugh's lead at the University of Iowa was Louis Pelzer, who grew up on an Iowa farm, earned his Ph.D. at Iowa, and went on to write several works of Iowa history. Orin G. Libby, who was born on a farm in Wisconsin and earned a Ph.D. at Wisconsin under Turner, taught at the University of North Dakota (1906-1945). ${ }^{23}$ Solon Justus Buck, who also grew up in Wisconsin, earned his B.A. from Wisconsin and his Ph.D. from Harvard under Turner and went on to teach at Indiana, Illinois, and Minnesota, where he revived the Minne-

21. Minutes, Board of Editors, 12/29/1913; Alvord to Albert Friedenberg, 3/17/1914; Shambaugh to Alvord, 4/3/1914; Alvord to MVHR Board of Editors, 3/31/1914, all in MVHA correspondence, vol. 1, Alvord Papers; Paxson, History of the American Frontier, preface.

22. Pease was a professor of history at Illinois from 1914 to 1948. "Historical News and Comments," Mississippi Valley Historical Review 35 (1949), 719-20. Illinois also produced Clarence E. Carter, born in Jacksonville, Illinois, who earned his B.A. from Illinois, his M.A. from Wisconsin, and his Ph.D. from Illinois in 1908, taught at Miami University in Ohio, and then edited the massive Territorial Papers series for the U.S. Department of State and then the National Archives, a series that included many midwestern states. Solon J. Buck, “Clarence E. Carter, 1881-1961," American Archivist 25 (1962), 59-60.

23. Martin Ridge, "Turner the Historian: A Long Shadow," Journal of the Early Republic 13 (1993), 137; Robert P. Wilkins, "Orin G. Libby, 1864-1952," Arizona and the West 16 (1974), 107; Gordon L. Iseminger, "Dr. Orin G. Libby: A Centennial Commemoration of the Father of North Dakota History," North Dakota History 68 (2001), 2-3. 
sota Historical Society. ${ }^{24}$ John D. Barnhart, born in Decatur, Illinois, took his B.A. from Illinois Wesleyan and, after several teaching stints, earned his Ph.D. in 1930 from Harvard, where he studied with Turner. Barnhart taught mostly at Indiana but also in Nebraska and Minnesota, edited the Indiana Magazine of History (1941-1955), and wrote several books about the Midwest. ${ }^{25}$ Frederic Logan Paxson was born in Pennsylvania and earned his Ph.D. from Pennsylvania, but turned to studying the West while teaching at Colorado and Michigan. In 1910 he replaced Turner at Wisconsin. ${ }^{26}$ In 1925 Paxson won the Pulitzer Prize for his broadly gauged book on the westward movement, History of the American Frontier, 1763-1893.

This founding generation of Prairie Historians had a mutually supportive relationship with a budding institution in the Midwest, the state historical society. Beginning in Wisconsin in the 1850s with the work of Lyman Draper, the Wisconsin Historical Society became a model for other midwestern states. ${ }^{27}$ Reuben Gold Thwaites of Oshkosh became secretary at the Wisconsin Historical Society in 1887 and abetted Turner's efforts to craft a regional historical consciousness. ${ }^{28}$ Milo Quaife, born near Nashua, Iowa, went to Grinnell College, earned a Ph.D.

24. Boyd, "State and Local Historical Societies," 32.

25. Barnhart to Hicks, n.d., folder 1925, carton 13, Hicks Papers, Bancroft Library, Berkeley, CA; "Memorial Tribute to John D. Barnhart," Indiana Magazine of History 64 (1968), 109-12. Barnhart taught at the University of Nebraska, Nebraska Wesleyan, and Minnesota Teachers College-Moorhead.

26. Paxson to Turner, 5/1/1906 and 3/30/1910, Frederick Jackson Turner Papers, Huntington Library, San Marino, CA; Ira G. Clark, "Frederic Logan Paxson, 1877-1948," Journal of the Southwest 3 (1961), 107.

27. Paul Hass, "Reflections on 150 Years of Publishing," Wisconsin Magazine of History 88 (2004-5), 4-5; John D. Hicks, "My Ten Years on the Wisconsin Faculty," Wisconsin Magazine of History 48 (1965), 308; William B. Hesseltine, Pioneer's Mission: The Story of Lyman Copeland Draper (Madison, WI, 1954).

28. Turner started teaching at Wisconsin in 1889 and "for the next dozen years was a staunch friend and colleague of Thwaites and an eloquent booster of the Wisconsin Historical Society, which inspired his research and teaching for forty years." Thwaites edited the Collections, edited and published 168 books, and also wrote 15 books himself. Hass, "Reflections on 150 Years of Publishing," 5. See Turner, Reuben Gold Thwaites: A Memorial Address (Madison, WI, 1914). When Turner returned to Wisconsin in 1889, he started "a formal seminary" in the Wisconsin Historical Society library and started to study the "social foundations of American history." Nettels, “History Out of Wisconsin," 114. 


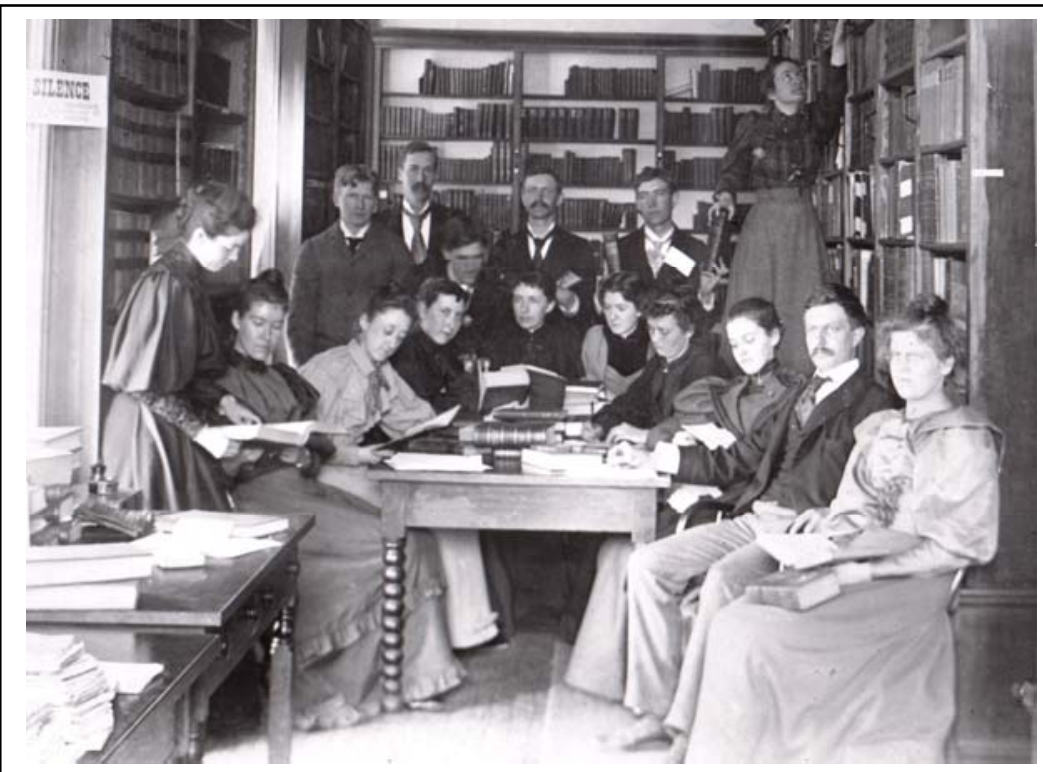

Frederick Jackson Turner conducted his American history seminar in an alcove of the Wisconsin Historical Society's library in the State Capitol. Turner is second from the right in the front row. Photo from the Wisconsin Historical Society, WHS Image ID 23174.

from the University of Chicago, and succeeded Thwaites as superintendent of the Wisconsin Historical Society when Thwaites died in 1913. ${ }^{29}$ Quaife launched the Wisconsin Magazine of History, served as president of the MVHA, edited the MVHR, and is remembered for his opposition to eastern bias in American history. ${ }^{30}$ Quaife was replaced at the Wisconsin Historical Society by Joseph Schafer, born in Grantsburg, Wisconsin, who earned a Ph.D. under Turner at Wisconsin and led the society until his

29. Paxson, who served on the search committee for the society's new leader, said that Quaife's history of Chicago was the "kind of historical work that we should like to see associated with the Society." Paxson to Turner, 12/11/1913, Turner Papers.

30. Quaife later moved to the Detroit Public Library to oversee the Burton Historical Collection, becoming known as the "unofficial voice of midwestern history." David A. Walker, "Milo Milton Quaife," in Wunder, ed., Historians of the American Frontier, 497-99; John D. Hicks, "State and Local History," Wisconsin Magazine of History 39 (1955-56), 136. 
death in 1941. ${ }^{31}$ More than a dozen Wisconsin Historical Society leaders and Wisconsin-connected scholars went on to become president of the MVHA. ${ }^{32}$ The cause of midwestern state historical societies was advanced by other, less well-known Prairie Historians, including George W. Martin and William Connelley in Kansas, Clarence and Clara Paine and Addison Sheldon in Nebraska, Doane Robinson in South Dakota, and Warren Upham in Minnesota. ${ }^{33}$ They all worked diligently to collect and publish material about midwestern history.

BUILDING ON THE FOUNDATION established by the first generation of Prairie Historians and their allies in midwestern historical societies, several scholars carried on in this tradition in subsequent years. Frederick Merk, born in Milwaukee, earned his B.A. at Wisconsin, worked at the Wisconsin Historical Society for five years, and then followed Turner to Harvard, where he earned his Ph.D. Merk would assume Turner's courses in western history at Harvard and train such students as Paul Gates, who became an expert on western land policy. ${ }^{34}$ John D. Hicks, born in a small town in Missouri, earned his Ph.D. at Wisconsin under Paxson, taught at Nebraska, and then replaced Paxson at Wisconsin in 1932. ${ }^{35}$ While teaching

31. Hass, "Reflections on 150 Years of Publishing," 8.

32. These included Orin G. Libby, Thwaites, Paxson, Quaife, Buck, Schafer, John D. Hicks, Carter, and Merle Curti. Nettels, "History Out of Wisconsin," 115.

33. Margaret Landis, "Connelley Kept Record Straight," Kansan, 11/17/1985; Edgar Langsdorf, "The First Hundred Years of the Kansas State Historical Society," Kansas Historical Quarterly 41 (1975), 265-425; Anne Polk Diffendal, "A Centennial History of the Nebraska State Historical Society, 1878-1978," Nebraska History 59 (1978), 333-34, 345-49, 357-64; Mary Wheelhouse Berthel and Harold Dean Carter, "The Minnesota Historical Society: Highlights of a Century," Minnesota History 30 (1949), 313-15; Russell W. Fridley, "Critical Choices for the 'Minnesota Historical Society,'" Minnesota History 46 (1978), 134, 136; J. L. Sellers, “A. E. Sheldon's History Gives Complete Story of State Development," Nebraska History 13 (1932), 110-12. On Iowa, see Benjamin F. Shambaugh, "A Brief History of the State Historical Society of Iowa," Iowa Journal of History and Politics 1 (1903), 139-52.

34. On Merk's admiration for Turner, see Rodman W. Paul, "Frederick Merk, Teacher and Scholar: A Tribute," WHQ 9 (1978), 142.

35. Hicks to John Barnhart, 5/21/1932, Barnhart Papers, Lilly Library, Indiana University, Bloomington, IN. 
at Nebraska, Hicks helped Everett Dick, who was born on a Kansas farm, win entry into Wisconsin, where Dick became a Paxson student. ${ }^{36}$ While at Wisconsin, Paxson also trained the Indiana-born historian R. Carlyle Buley, who went on to teach at Indiana and won the Pulitzer Prize in 1951 for his twovolume history The Old Northwest. ${ }^{37}$

Prominent Prairie Historians also emerged from outside the immediate orbit of Wisconsin. Allan Bogue, born on a farm in Ontario, earned his Ph.D. under Gates at Cornell and went on to teach at Iowa and then Wisconsin, where he became the Frederick Jackson Turner Professor of History. At Iowa, Pelzer trained Vernon Carstensen, who was born on an Iowa farm and went on to teach at Wisconsin and Washington; and Elmer Ellis, who was from North Dakota and who went on to teach at Missouri. ${ }^{38}$ At Kansas, Frank Hodder, who was from Aurora, Illinois, trained James Malin, who was originally from North Dakota and earned the first doctorate in history granted by Kansas. ${ }^{39}$

In addition to organizing the MVHA to promote midwestern history, the Prairie Historians remained strongly committed to aiding the state historical societies of the Midwest that flour-

36. Christine Nasso, ed., "Everett Dick," Contemporary Authors (Detroit, 1977).

37. Buley to Stanley Pargellis, 8/15/1944, Carlyle Buley Papers, Indiana Historical Society, Indianapolis, IN; R. Carlyle Buley, The Old Northwest: Pioneer Period, 1815-1840, 2 vols. (Indianapolis, 1950). At Indiana, Buley followed in the tradition of Logan Esarey, who was from rural Indiana, earned an Indiana Ph.D., and launched the professional study of the state's history. R. Carlyle Buley, "Logan Esarey, Hoosier," Indiana Magazine of History 38 (1942), 348.

38. Pelzer also edited the MVHR (1941-1946). Ellis earned his M.A. at the University of North Dakota under Libby, and at Missouri Ellis trained historians Lewis Atherton, from Missouri, and Gilbert Fite, from South Dakota. During those years, Fred Shannon, who was from Missorui and Indiana, also earned his Ph.D. at Iowa working under Arthur Schlesinger Sr.; his dissertation became the Pulitzer Prize-winning two-volume book The Organization and Administration of the Union Army, 1861-1865 (Cleveland, 1928). Robert H. Jones, "Fred Albert Shannon," Great Plains Journal 19 (1979), 55.

39. Malin said that Hodder "meant more to the cause of history in Kansas than any other man." James Malin, "Frank Heywood Hodder, 1860-1935," Kansas Historical Quarterly 5 (1936), 115; Thomas B. Colbert, "James C. Malin," Great Plains Journal 19 (1979), 48. At first, Hodder was not enthused about the MVHA, but became its president in 1925. Alvord, Shambaugh, and James E. James, Memo to MVHA Executive Committee, circa 1913, MVHA correspondence, vol. 1, Alvord Papers; Buck to Alvord, 4/6/1916, MVHA correspondence, vol. 2, Alvord Papers. 


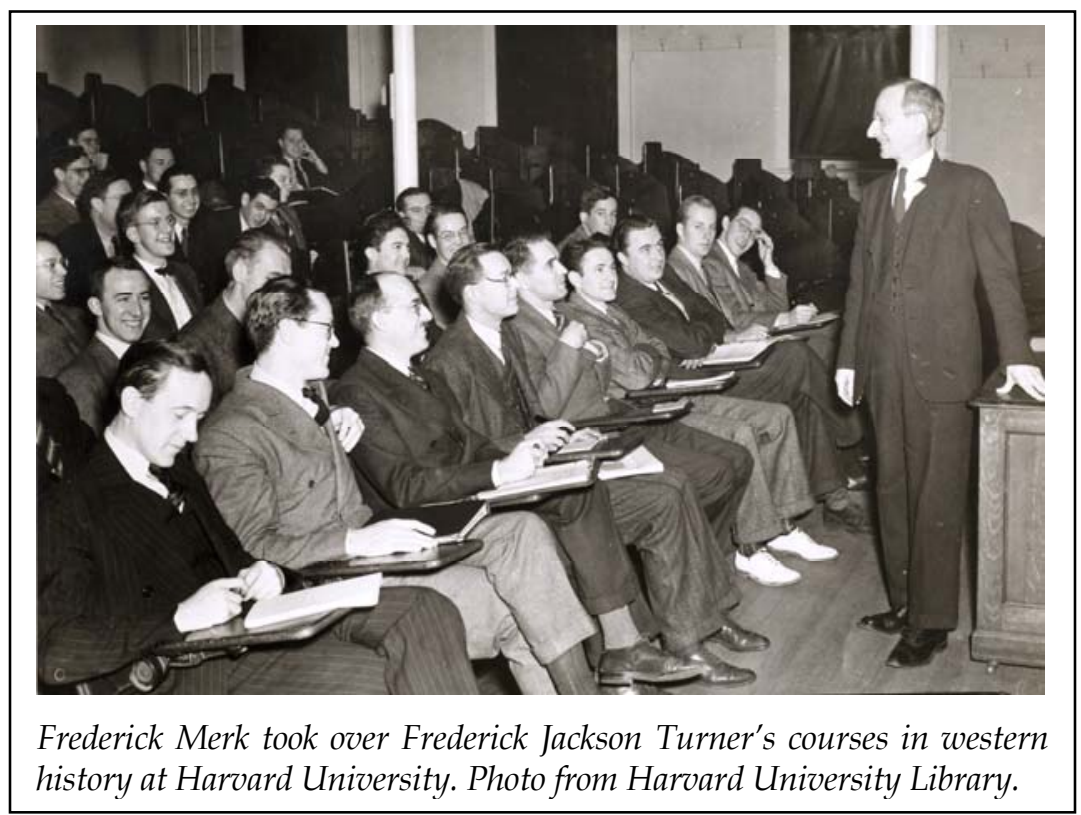

ished during the late nineteenth and early twentieth centuries. 40 In 1916, in an emblematic moment, Shambaugh and Buck talked until 2:00 a.m. at a history conference about Buck's speech, "The Functions of a State Historical Society." 41 As president of the MVHA, Paxson appointed Alvord to chair the association's committee on "The Relation of Historical Societies and Departments of History." 42 Alvord was a good choice; he had collected a massive amount of materials for the Illinois Historical Survey and had turned the Illinois Historical Collections he had created into a "veritable laboratory of state history." 43 The Illinois Centennial Commission named Alvord the editor and organizer of

40. Boyd, "State and Local Historical Societies," 28, 33; Andrew R. L. Cayton and Susan E. Gray, "The Story of the Midwest: An Introduction," in The American Midwest: Essays on Regional History (Bloomington, IN, 2001), 22; Buley, The Old Northwest, 551-56; Eric Hinderaker, "Liberating Contrivances: Narrative and Identity in Midwestern Histories," in The American Midwest, 53-65, 215n.

41. Buck to Alvord, 5/3/1916, MVHA correspondence, vol. 2, Alvord Papers.

42. Clara Paine to Alvord, 10/18/1916, MVHA correspondence, vol. 2, Alvord Papers.

43. Buck, "Clarence Walworth Alvord," 311. 
a multivolume history of Illinois, which was "generally recognized as setting a new standard for state histories." 44 Working as a graduate assistant with Alvord at Illinois, Theodore Pease cowrote "Archives of the State of Illinois" with Alvord. As a professor at Illinois, Pease took over as editor of the Illinois Historical Collections in 1920, when Alvord moved to Minnesota, and edited it until 1939. Pease also traveled throughout Europe collecting materials from European archives relating to early Illinois, making copies before some were destroyed during World War II. ${ }^{5}$ Pease edited many other collections and, in a measure of his dedication to saving the remnants of the past, he became the editor of the newly formed journal American Archivist in the 1930s. Pease was a member of the State Historical Society of Illinois for 39 years and also served as its president. ${ }^{46}$

In addition to the frenetic activity in Illinois and the longstanding work of the Wisconsin Historical Society, the historical societies in other midwestern states benefited from the work of the Prairie Historians. Shambaugh and Pelzer remained committed to supporting the State Historical Society of Iowa. Solon Buck "rebuilt" the Minnesota Historical Society, became its superintendent, launched its quarterly journal, edited a fourvolume history of Minnesota, encouraged the organization of county historical societies, and generally "proceeded to reorganize and revolutionize the institution." 47 In North Dakota, Orin Libby started "reorganizing the moribund State Historical Society," served as its secretary for four decades, planned six state parks, started publishing the Collections, and launched the North Dakota Historical Quarterly in 1926. For all of his work,

44. Ibid., 311-12. The series included Buck's Illinois in 1818 (1917), Pease's The Frontier State, 1818-1848 (1918), and Alvord's The Illinois Country, 1673-1818 (1920).

45. J. G. Randall, "Theodore Calvin Pease," Journal of the Illinois State Historical Society 41 (1948), 354, 357-59; "Historical News and Comments," 720.

46. Randall, "Theodore Calvin Pease," 361-62; "Historical News and Comments," 720. Pease also chaired the AHA's Manuscripts Commission. In 1941 Buck became the second U.S. Archivist.

47. Theodore Blegen to John Barnhart, 11/12/1931, Barnhart Papers; Theodore C. Blegen, "Solon Justus Buck-Scholar-Administrator," American Archivist 23 (1960), 259-61. 
Libby became known as the "father of North Dakota history." 48 In addition to assisting state historical societies and publishing in the MVHR, the Prairie Historians actively used the pages of state history journals to publish their research and urged journal editors to reach out to professional historians. ${ }^{49}$

The Prairie Historians' dedication to state historical societies was complemented by an intense commitment to state and local history. In his 1923 presidential address to the MVHA, Solon Buck lauded the increasingly "scientific" work of the "historical societies of the Mississippi valley" but also noted the growing interest among the region's historians in state and local history. ${ }^{50}$ Buck's student Theodore Blegen, who earned a Ph.D. at Minnesota and followed Buck as superintendent of the Minnesota Historical Society, denounced the "inverted provincialism" of "urbane and cosmopolitan" scholars who dismissed "regionalists" and "rejected the near-at-hand as local and insignificant." 51 Buck praised Blegen's work on Minnesota history, and Frederick Merk said James Malin's study of prairie locales set “a pattern for local history that much needs to be followed." 52 Throughout his career, Allan Bogue would honor Malin's ad-

48. Wilkins, “Orin G. Libby, 1864-1952," 108, 110; Iseminger, “Dr. Orin G. Libby," 6-7; Waldemar Westergaard, "Orin Grant Libby," North Dakota Historical Quarterly 42 (1956), 70; Unknown to Paxson, 12/12/1913, Libby Papers, University of North Dakota, Grand Forks, ND.

49. See, for example, John Barnhart to John Hicks, 6/19/1928, Hicks Papers. On such journals, see James H. Rodabaugh, "Historical Societies: Their Magazines and Their Editors," Wisconsin Magazine of History 45 (1961-62), 115-23.

50. Solon J. Buck, "The Progress and Possibilities of Mississippi Valley History," MVHR 10 (1923), 5-6. See also Solon J. Buck, "The Upper Missouri Historical Expedition," MVHR 12 (1925), 385-91. Buck's speech signaled the Prairie Historians' professed devotion to local studies. See Hicks, "State and Local History,"137; Shambaugh, The Constitutions of Iowa, 11; Schroder, "Benjamin F. Shambaugh," 614; Walker, "Milo Milton Quaife," in Wunder, ed., Historians of the American Frontier, 499; Alvord, "The Study and Writing of History in the Mississippi Valley," 98-110; Robert Galen Bell, "James C. Malin and the Grasslands of North America," Agricultural History (hereafter Ag History) 46 (1972), 415.

51. Theodore C. Blegen, Grassroots History (Minneapolis, 1947), 5. Blegen said that Buck's "instruction turned me away from the Stuart period of English history into American western and American social history." Blegen, "Solon Justus Buck-Scholar-Administrator," 260.

52. Buck to Blegen, 2/4/1937, box 6, Buck Papers, National Archives; Merk to Malin, 3/15/1952, Malin Papers, Kansas State Historical Society, Topeka, KS. 
monition that "the good historian should master both local and national history." 53 John Hicks echoed Malin's point, arguing that the historian "should be able to weave into the national story the complicated contributions of localities, states, and sections, and yet not lose himself in insignificant detail." 54 Only on the basis of strong local histories, the Prairie Historians argued, could larger interpretations properly be made. ${ }^{55}$ They found it frustrating that other observers failed to see the larger importance of local history and that they continued to treat it as "provincial." 56 Malin noted that local history had been in "disrepute" and lamented the "virtual elimination of local history from the scene." In place of historical writing "from the top down," Malin argued for a "bottom up" history that recognized "the basic fact that all history of human activity must necessarily start from the individual at a particular time and place." 57

THE ENERGY expended organizing the MVHA, aiding state historical societies, and advocating state and local history underscored the regionalist sensibility of the Prairie Historians and their tilt toward studies of midwestern history. The MVHR was purposely geared toward the history of what Shambaugh called "the Great Valley." 58 Alvord said that the MVHR "belongs to all the historians and historical organizations of the Mississippi Valley." The journal featured reports on "historical activities" in regions designated as the "Old Northwest and Canada" and the "Trans-Mississippi Northwest." 59 The original

53. Allan G. Bogue, “Tilling Agricultural History with Paul Wallace Gates and James C. Malin," Ag History 80 (2006), 437, 448, 453.

54. Hicks, "State and Local History," 137.

55. Buck to Barnhart, 1/18/1938, Barnhart Papers; James C. Malin, "On the Nature of Local History," Wisconsin Magazine of History 40 (1957), 227; Frederic L. Paxson, "A Generation of the Frontier Hypothesis: 1893-1932," Pacific Historical Review 2 (1933), 39; Iseminger, “Dr. Orin G. Libby,” 3.

56. Buck, "Clarence Walworth Alvord," 320.

57. Malin, "On the Nature of Local History," 228.

58. Minutes, Board of Editors, 12/29/1913, and Shambaugh to Alvord, 1/16/ 1914, MVHA correspondence, vol. 1, Alvord Papers.

59. Alvord circular letter, 3/7/1914, and Alvord to the Authors of "Historical Activities," 2/10/1914, MVHA correspondence, vol. 1, Alvord Papers; James 


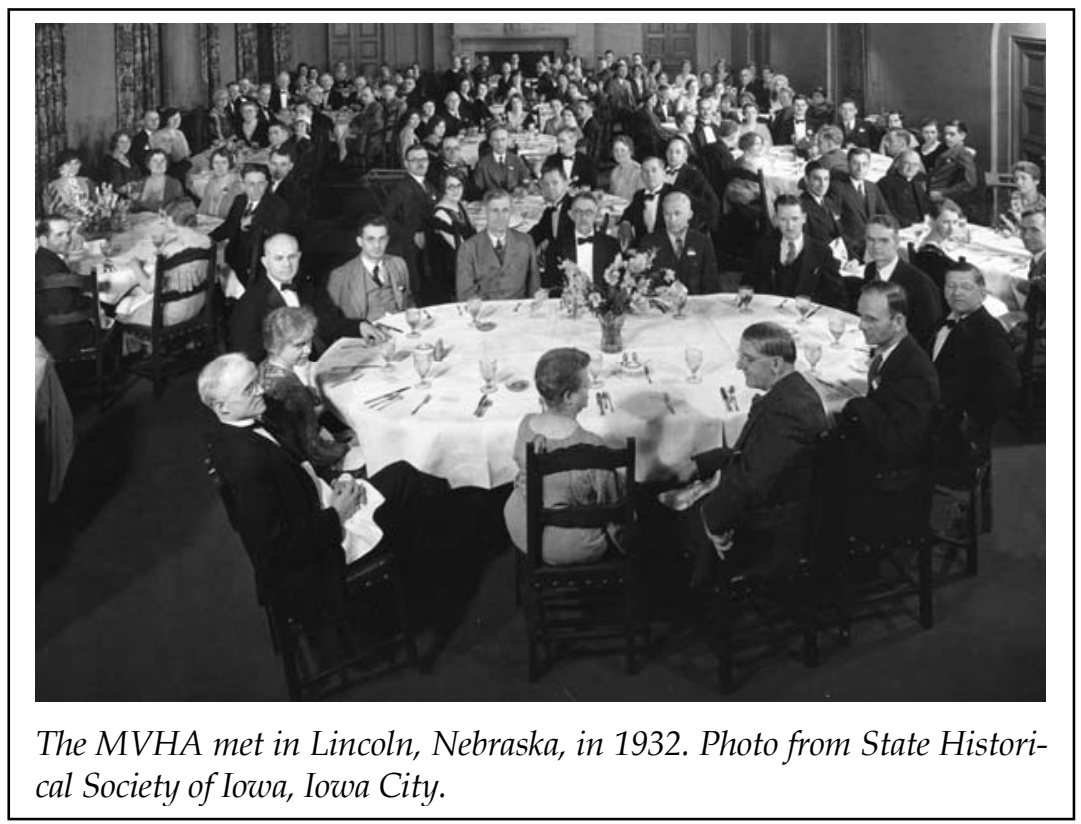

organizers of the MVHA worked diligently to attract historians at regional universities such as Minnesota, Kansas, Nebraska, Michigan, Missouri, Iowa, Cincinnati, and Chicago. 60 The Prairie Historians also tried to keep the presidency of the MVHA in the hands of scholars who focused on western history. ${ }^{61}$ Alvord thought the MVHA would become a "laughing stock" by going "so far afield as to elect a modern history scholar for our presi-

Sellers to Solon Buck, 8/2/1929, Sellers Papers, University of Nebraska Archives, Lincoln. When the MVHA was searching for an editor of the MVHR, James Sellers said that the MVHA "can hardly afford to go east of the Alleghenies to secure an editor." Sellers to Hicks, 7/17/1940, Sellers Papers. James Sellers, who was born in North Platte, Nebraska, earned his Ph.D. from Wisconsin in 1922, taught at Nebraska (1930-1959), edited Nebraska History, and served as president of the MVHA. James C. Olson, "James Lee Sellers," Nebraska History 47 (1966), 123-26.

60. Alvord circular letter, 1/30/1914, and Clarence Paine to Alvord, 3/4/1914, MVHA correspondence, vol. 1, Alvord Papers.

61. Alvord to Clarence Paine, 6/17/1914, MVHA correspondence, vol. 1, Alvord Papers; Vernon Carstensen to Merle Curti, 2/14/1951, folder 18, box 8, Curti Papers; Paul Gates to Ray Billington, 11/15/1951, Paul Gates Papers, Cornell University, Ithaca, NY. 
dent." 62 In keeping with its regional focus, the MVHA often met in such cities as Lincoln, Lake Minnetonka, Iowa City, Bloomington, Omaha, Grand Forks, St. Paul, Madison, Des Moines, Vincennes, Columbia, Indianapolis, Milwaukee, Cedar Rapids, Columbus, Rock Island, and Cincinnati. ${ }^{63}$

This dedication to the regional dimension of midwestern history stemmed from Turner's leadership. Since Turner first challenged the dominance of the East and promoted the study of the Midwest, regionalism was thought to be "synonymous with Frederick Jackson Turner." 64 Turner was, after all, a "son of the Prairies," and his writings were "in fact predicated largely upon the unique conditions of the Prairie West and became the basis of an historical school that had its center in that region." 65 As early as 1887 Turner had said that he would focus "chiefly upon the Northwest and more generally upon the Mississippi Valley" and those "peopling the prairie." 66 Turner remained attuned to "state resistance to the nationalizing process" and regional "resistance to national homogeneity." 67 Michael Steiner argues that the "furor" over the frontier thesis has "blinded" historians to "Turner's more persistent concern" with regionalism, which led him to win the Pulitzer Prize. 68 The "rallying cry"

62. Alvord to Clarence Paine, 6/24/1914, MVHA correspondence, vol. 1, Alvord Papers.

63. Sellers, "The Semicentennial of the Mississippi Valley Historical Association," 516-17. For a negative assessment of the MVHA's regionalism, see Ray Allen Billington, "From Association to Organization: The OAH in the Bad Old Days," JAH 65 (1978), 75-84.

64. Richard Jensen, “On Modernizing Frederick Jackson Turner: The Historiography of Regionalism," WHQ 11 (1980), 307.

65. Earle D. Ross, “A Generation of Prairie Historiography,” MVHR 33 (1946), 392-93.

66. Steiner, "The Significance of Turner's Sectional Thesis," 442 (quoting Turner). 67. Frederick Jackson Turner, "Is Sectionalism in America Dying Away?" American Journal of Sociology 13 (1908), 661-62; Turner to Barnhart, 4/1/1931, Barnhart Papers.

68. Steiner, "The Significance of Turner's Sectional Thesis," 439. Turner was posthumously awarded the Pulitzer Prize for his book The Significance of Sections in American History (New York, 1932). Turner used the term sectionalism because regionalism was "not widely used in the United States until the last decade of his life." Michael C. Steiner, "Frontier to Region: Frederick Jackson Turner and the New Western History," Pacific Historical Review 64 (1995), 486. 
for regional history, Fulmer Mood once reminded historians, "came from Turner, at Madison." 69

While amenable to Turner's regionalist ethos and his emphasis on the role of the Midwest in American history, the Prairie Historians were certainly willing to modify his findings. ${ }^{70}$ If Turner and some Prairie Historians had emphasized the rapid Americanization of immigrant settlers in the Midwest, others were closely attuned to ethnic persistence. ${ }^{71}$ Theodore Blegen, for example, who became a professor at Minnesota, always advocated more work on the "immigrant factor." 72 If Turner had emphasized the uniqueness of frontier democracy too much and had not adequately accounted for European and eastern precedents, the Prairie Historians accepted the critics' points. ${ }^{73}$ If Turner saw the frontier as a social "safety valve" for the nation, the Prairie Historians recognized that the frontier did less to relieve pressure on the body politic than Turner thought. Paxson rather enjoyed the "good row" during the 1930s over Turner's "'safety valve' idea." 74

69. Fulmer Mood, "The Theory of the History of an American Section in the Practice of R. Carlyle Buley," Indiana Magazine of History 48 (1952), 14.

70. John Morton Blum, “A Celebration of Frederick Merk, 1887-1977," Virginia Quarterly Review 54 (1978), accessed at www.vqronline.org/articles/1978/ summer/blum-celebration/.

71. Paxson, "A Generation of the Frontier Hypothesis," 43-46; Gerald D. Nash, Creating the West: Historical Interpretations, 1890-1990 (Albuquerque, NM, 1991), 30, 35; Louis Pelzer, Merle Curti, Edward Everett Dale, Everett Dick, and Paul W. Gates, "Projects in American History and Culture," MVHR 31 (1945), 510.

72. Blegen to Merle Curti, 5/25/1944, folder 4, box 6, Curti Papers; Solon Buck letter, 9/27/1935, box 6, Solon Buck Papers. See also Theodore C. Blegen, Norwegian Migration to America, 2 vols. (Northfield, MN, 1931, 1940). The Prairie Historians also frequently corresponded with Turner student Marcus Hansen, who was from Iowa, and Carl Wittke, who was from Ohio. Hansen and Wittke both emphasized immigration. See Marcus L. Hansen, The Atlantic Migration, 1607-1860 (Cambridge, MA, 1940), which won the Pulitzer Prize in 1941; and Carl F. Wittke, We Who Built America: The Saga of the Immigrant (New York, 1939). See also Joseph Schafer, The Yankee and the Teuton in Wisconsin (Menasha, WI, 1922). On Turner as the "key figure in [the] reorientation of American historiography" toward immigration, see Allan H. Spear, "Marcus Lee Hansen and the Historiography of Immigration," Wisconsin Magazine of History 44 (1961), 258-59.

73. Nash, Creating the West, 31.

74. Paxson to Malin, 11/16/1936, Malin Papers ("row" quote); Paxson to Joseph Schafer, folder 5, box 3, Schafer Papers, Wisconsin Historical Society; 
A number of the Prairie Historians did, however, carry on Turner's emphasis on the prairie Midwest as a unique meeting ground where diverse peoples and cultures successfully mixed, giving rise to a more egalitarian social order. The distinctions between the North and South were more pronounced in the East, Alvord said, but in the West there was more "friendly intercourse" among peoples. ${ }^{75}$ Paxson described the mixing of colonial settlers and German and Scotch-Irish immigrants in the midwestern backcountry and explained how their "divergent and contradictory traits" were brought into the "melting pot of the interior valleys" and "speedily submerged in the common nationality." 76 Carlyle Buley noted the "dual heritage" of paternalistic New England Puritanism and "Scotch-Irish frontier individualism" in the Midwest. ${ }^{77}$ John Barnhart described the many "racial and national strains" in the Midwest, including the important role of southern immigrants. ${ }^{78}$ Because of this great diversity, Libby said, midwestern history was "amply continental, never petty or sectional." 79 While recognizing cultural persistence among these groups, the Prairie Historians also sought to understand the "solvent power" of the American experience in contrast to a divided and balkanized Europe. ${ }^{80}$

Gates to Merk, 5/1/1935, Gates Papers; Buley, The Old Northwest, 10 n. 17; Fred A. Shannon, "A Post Mortem on the Labor-Safety Valve Theory," Ag History 19 (1945), 31-37; Joseph Schafer, "Was the West a Safety Valve for Labor?" MVHR 24 (1937), 299-314; Henry M. Littlefield, "Has the Safety Valve Come Back to Life?" Ag History 38 (1964), 47-49.

75. Alvord, "The Study and Writing of History in the Mississippi Valley," 101; Clarence Walworth Alvord, "The Relation of the State to Historical Work," Minnesota History Bulletin 1 (February 1915), 16.

76. Paxson, History of the American Frontier, 7.

77. Buley, The Old Northwest, 2:1.

78. John D. Barnhart, Valley of Democracy: The Frontier versus Plantation in the Ohio Valley, 1775-1818 (Bloomington, IN, 1953), 7; “Memorial Tribute to John D. Barnhart," 110; John Barnhart, "Sources of Southern Migration into the Old Northwest," MVHR 22 (1936), 49-62; idem, "The Southern Influence in the Formation of Indiana," Indiana Magazine of History 33 (1937), 26-76; idemt, "The Southern Influence in the Formation of Illinois," Journal of the Illinois State Historical Society 32 (1939), 358-78.

79. Orin G. Libby, "Some Aspects of Mid-West America," Minnesota History Bulletin 4 (February/May 1922), 214.

80. Pelzer et al., "Projects in American History and Culture," 510. 
The social and ethnic mixing in the Midwest, the Prairie Historians thought, was accompanied by a greater degree of egalitarianism in the region. Shambaugh said that the "frontier was a great leveler" that "fostered the sympathetic attitude" and made "men plain, common, unpretentious" and "really democratic." Most settlers were small landholders and thus, Barnhart said, the Midwest was a "poor man's home" where people participated in civic affairs and the "pretensions of the aristocrats" were shunned. Buley found that on the midwestern frontier egalitarianism was the norm: "Equality was not a theory or creed; it was merely a natural circumstance." The midwesterner thought he could "serve in any political capacity from assistant dog catcher or fence viewer to governor or even president." Buley pointed to nineteenth-century travelers who also noted this egalitarianism and the "American's tendency to profanity, tobacco chewing, and leaning back on the hind legs of a chair, his devotion to newspapers." 81

BY HIGHLIGHTING the growth of democratic attitudes in the Midwest, the Prairie Historians were tracing what they saw as the unique nature of American democracy. This focus on what has come to be called American exceptionalism is often traced to Turner. ${ }^{82}$ The Prairie Historians continued this tradition by frequently noting distinctions between midwestern democratic progress and reactionary regressions in Europe. The states and provinces of the vast interior region of the United States were unique, Libby wrote, especially in comparison to Europe, where a "state of tension exists, resulting from centuries of conflict and rivalry." The Prairie Historians also noted how democratic reformers in other countries borrowed American ideals. Theodore Pease explained how the "stirrings of revolution and liberty in Europe and South America" took place "under the influence and example of republican America."

81. Shambaugh, The Constitutions of Iowa, 25; John D. Barnhart, "The Democratization of Indiana Territory," Indiana Magazine of History 43 (1947), 9-10; Buley, The Old Northwest, 1:31, 2:2, 489.

82. Nettels, "History Out of Wisconsin," 116; Francois Furstenberg, "The Significance of the Trans-Appalachian Frontier in Atlantic History," AHR 113 (2008), 676; Ridge, “Turner the Historian,” 137. 
Merk praised Merle Curti, who was a product of Papillion, Nebraska, and who had studied with Turner at Harvard, for explaining the role of American democratic ideas in the reform efforts of mid-nineteenth-century Germany and German reformers' embrace of the American model of framing a constitution for a new Germany. Merk also appreciated Curti's article outlining European fears of American democracy during the early nineteenth century. Curti had emphasized the extent of anti-Americanism among European conservatives, who saw the new American republic as "dangerous to the established order of the Old World." From Turner to Curti at Wisconsin, where Curti replaced Hicks, and among the Prairie Historians generally, the nation's unique heritage was a given. Indeed, Wisconsin's history department and the Wisconsin Historical Society, Curtis Nettels noted, "fostered writings" that explained "why the United States [was] a distinctive nation." 83

The most important component of the exceptionalist story for the Prairie Historians was the development of American democracy on the midwestern frontier, which constituted a dominant and unifying theme in their writing. Turner set the tone for this emphasis in his 1893 address in which he said that the "most important effect of the frontier has been in the promotion of democracy here and in Europe." In his presidential address to the MVHA in 1952, Curti stressed how Turner had brought the "democratic theme" into American historical discourse. Hicks praised Curti's speech for its attention to the "essentials of democracy" and recounted his own efforts to capture and communicate the "various ingredients of the American concept of democracy" to broader audiences. In 1943 Hicks himself had written A Short History of American Democracy. In Curti's The Growth of American Thought, which won the Pulitzer Prize in 1944 and was dedicated to the memory of Turner, Curti also emphasized the rise of democratic modes of thought in the West. The year after Curti's presidential address, Barnhart published The

83. O. G. Libby, “The New Northwest,” MVHR 7 (1921), 346; Pease, The Frontier State, 20; Frederick Merk to Merle Curti, 6/28/1926, 3/14/1949, and 11/14/1950, folder 1, box 26, Curti Papers; Merle Curti, "The Reputation of America Overseas (1776-1860)," American Quarterly 1 (1949), 59; Nettels, "History Out of Wisconsin," 115-16. 
Valley of Democracy, which encapsulated many of the democratic themes embraced by the Prairie Historians and summarized much of their work. In the book, after thanking Turner, Alvord, Buck, and Pease, Barnhart explained the "significant victories" for American democracy in the Midwest, where the "aristocracy inherited from colonial days" was destroyed. ${ }^{84}$

FOR THE PRAIRIE HISTORIANS, a focus on the development of American democracy involved close attention to law and constitutionalism. ${ }^{85}$ Working under Turner at Wisconsin, for example, Orin Libby closely analyzed the bases of support for the ratification of the federal Constitution. ${ }^{86}$ Because of its fundamental importance for the legal foundations of the Midwest, the Prairie Historians also extensively studied the Northwest Ordinance. Theodore Pease said that the members of the MVHA considered it "secondary only to the Constitution." 87 Pease had studied constitutional history at the University of Chicago with Andrew McLaughlin, who was born in Beardstown, Illinois, and served as the fifth president of the MVHA. ${ }^{88}$

84. Turner, "The Significance of the Frontier in American History," in Rereading Frederick Jackson Turner: "The Significance of the Frontier in American History" and Other Essays (New Haven, CT, 1998), 53; Merle Curti, "The Democratic Theme in American Historical Literature," MVHR 39 (1952), 10, 12-13; Hicks to Curti, 5/6/1952, folder 17, box 19, Curti Papers; John D. Hicks, A Short History of American Democracy (Boston, 1943); Merle Curti, The Growth of American Thought (New York, 1943); Barnhart, Valley of Democracy, ix, 3, 4.

85. Curti treated constitutionalism as an "essential element of democracy." Curti, "The Democratic Theme in American Historical Literature," 8.

86. Libby's dissertation under Turner about the ratification votes on the federal Constitution has been described as "Libby's magnum opus" and the "foundation for a new sophisticated study of the Constitution" that "brought him immediate acclaim in the American historical profession." Wilkins, "Orin G. Libby, 1864-1952," 107-8. See also Iseminger, "Dr. Orin G. Libby," 3.

87. Pease, "The Ordinance of 1787," 167.

88. McLaughlin's Constitutional History of the United States (New York, 1936) won the Pulitzer Prize. Curti, in "The Democratic Theme in American Historical Literature," 18, said that McLaughlin was a "pioneer" in bringing the theme of democracy into American history. See McLaughlin's presidential address to the AHA, "American History and American Democracy," AHR 20 (1915), 255-76, along with his Steps in the Development of American Democracy (New York, 1920) and "The Uses of an Historical Society," North Dakota Historical Society Collections 1 (1906), 53-67. 
Pease turned his dissertation into his first book, in which he connected English Leveller ideology to the development of American constitutionalism, and he edited the Laws of the Northwest Territory. 89 When McLaughlin had moved to Chicago, Paxson succeeded him at Michigan, took over his "Constitutional Law and Political Institutions" class, and developed a strong interest in western constitutions. ${ }^{90}$ After moving to Wisconsin, Paxson also pushed his advisee John Hicks to study western constitutions and "brushed aside" Hicks's initial plan to study Populism. ${ }^{91}$ Hicks discussed his work on constitutional history with Barnhart, who also focused on the constitutional development of the Midwest. ${ }^{92}$ Shambaugh wrote The Constitutions of Iowa, and Buck, after he moved to the National Archives, published works on the ratification of the Constitution and the Bill of Rights. ${ }^{93}$ When focusing on the constitutional development of the West, Pease, along with others, noted westerners' debts to

89. Theodore Pease, The Leveller Movement: A Study in the History and Political Theory of the English Great Civil War (Washington, DC, 1916). The book won the Herbert Baxter Adams Prize. Johannsen, "Introduction," The Frontier State, xv; R. Douglas Hurt, "Theodore Calvin Pease," in Wunder, ed., Historians of the American Frontier, 472. The book began as an assignment in McLaughlin's seminar at Chicago. Randall, "Theodore Calvin Pease," 355, 360; Theodore Pease, The Laws of the Northwest Territory, 1788-1800 (Springfield, IL, 1925).

90. Clark, “Frederic Logan Paxson, 1877-1948," 108; Frederic Paxson, “The Constitution of Texas, 1845," Southwestern Historical Quarterly 18 (1915), 386-98; idem, "A Constitution of Democracy: Wisconsin, 1847," MVHR 2 (1915), 3-24; idem, "The Admission of the 'Omnibus' States, 1889-1890," Proceedings of the Wisconsin State Historical Society 49 (1911), 76-93; idem, "Influence of Frontier Life on the Development of American Law," Proceedings of the Wisconsin State Historical Society 13 (1919-21), 477-89.

91. John D. Hicks, "My Years as a Graduate Student," Wisconsin Magazine of History 47 (1964), 283. See Hicks, The Constitutions of the Northwest States (Lincoln, NE, 1924). After moving to Berkeley, Paxson advised Earl Pomeroy, who studied the development of western territories and drew heavily on Clarence Carter's collections of documents about the territories. Earl S. Pomeroy, Territories and the United States, 1861-1890: Studies in Colonial Administration (Philadelphia, 1947).

92. Hicks to Barnhart, 6/4/1935, Barnhart Papers; John Barnhart, "Sources of Indiana's First Constitution," Indiana Magazine of History 39 (1943), 55-94; idem, "The Tennessee Constitution of 1796: A Product of the Old West," Journal of Southern History 9 (1943), 532-49; idem, "The Democratization of Indiana," Indiana Magazine of History 43 (1947), 1-22.

93. Buck to Hicks, 5/26/1936, box 8, Solon Buck Papers. 
the East and England, providing another qualification to Turner's overemphasis on the uniqueness of frontier conditions. ${ }^{94}$

In addition to seeing constitutionalism as a core component of the American democratic tradition, the Prairie Historians paid particular attention to the popular assertion of democratic rights in campaigns and elections. Most prominently, the Prairie Historians saw democratic passions and the influence of backcountry and frontier norms at work in the Populist rebellion of the late nineteenth century; their resulting research gave birth to Populist historiography. Turner called attention to farmer activism, and his more general assertion of the importance of western history served as a "historiographic counterpart of the farmer's revolt." 95 Turner's student Solon Buck began the tradition of focused studies of farmer activism with his book The Granger Movement, which provided the "scholarly foundation" for studying Populism and "opened the way to scores of books and articles" about Populism. ${ }^{96}$ Paxson praised Buck's book in the first issue of the MVHR and linked the democratic energy of farmer movements to the Midwest's frontier heritage of democracy. Paxson saw the frontier's political culture "undergoing transmutation into agrarian influence." 97 Buck followed The Granger Movement with the publication of The Agrarian Crusade in 1920.

John Barnhart and John Hicks followed in this tradition. Barnhart consulted with Turner when he pursued his graduate work on Nebraska Populism, and his first two published articles were about Populism. ${ }^{98}$ The first, published in 1925, noted that

94. Hurt, "Theodore Calvin Pease," in Wunder, ed., Historians of the American Frontier, 474.

95. Steiner, “The Significance of Turner's Sectional Thesis," 443.

96. Solon J. Buck, The Granger Movement: A Study of Agricultural Organization and Its Political, Economic, and Social Manifestations, 1870-1880 (Cambridge, MA, 1913); Blegen, "Solon Justus Buck-Scholar-Administrator," 260. See also Buck, "Agricultural Organization in Illinois, 1870-1880," Journal of the Illinois State Historical Society 3 (1910), 10-23.

97. Frederic Paxson, review of Solon Buck, The Granger Movement, in MVHR 1 (1914), 139; Paxson, History of the American Frontier, 573.

98. Ridge, “Turner the Historian," 143 n. 36 (on Barnhart and Turner). Merk, Arthur Schlesinger Sr., and Barnhart agreed that Schlesinger would be the first reader of Barnhart's dissertation on Nebraska Populism. Merk to Barnhart, 2/19/1926, Barnhart Papers; "Memorial Tribute to John D. Barnhart," 111; John Barnhart, "Rainfall and the Populist Party in Nebraska," American Political 
the "significance of Populism is being increasingly recognized" and cited Buck's books and a number of new articles in the MVHR, the Indiana Magazine of History, and the Iowa Journal of History and Politics. ${ }^{99}$ During the 1920s, while teaching at Nebraska, Hicks also turned to the study of Populism. Paxson, who had earlier vetoed Hicks's plan to study Populism in graduate school at Wisconsin, was enthused about Hicks's Populism research and urged him to study agrarian activism past 1900 and even to compare American Populism with French "debtor psychology" and opposition to paying war debts after World War I. ${ }^{100}$ Hicks and Buck discussed Hicks's new work on Populism, and Hicks and Barnhart collaborated on studies of Populism during these years. ${ }^{101}$ Hicks's work resulted in the publication of The Populist Revolt, which was written "in the context of the Turner thesis." 102 Merk was enthusiastic about the "sympathetic yet shrewd judgments" in Hicks's book, which he called the "definitive book on Populism." 103 Merk similarly saw Populism as a product of the settlement of the West. ${ }^{104}$ Hicks later gave himself the "task of finding out what had happened to the farmers of the Middle West after Populism." He put his research assistant Theodore Saloutos to work on the project and,

Science Review 19 (1925), 527-40; John Barnhart and John Hicks, "The Farmers' Alliance," North Carolina Historical Review 6 (1929), 254-80.

99. Barnhart, "Rainfall and the Populist Party in Nebraska," 527.

100. Paxson to Hicks, 12/1/1928 and 10/11/1930, Hicks Papers.

101. Buck to Hicks, 1/2/1929, Hicks Papers; Barnhart to Hicks, 1/21/1925, 12/8/1925, 7/16/1928, and 8/13/1930, Hicks Papers; Hicks to Barnhart, 5/7/ 1932, Barnhart Papers.

102. John D. Hicks, The Populist Revolt: A History of the Farmers' Alliance and the People's Party (Minneapolis, 1931); Martin Ridge, "Populism Redux: John D. Hicks and The Populist Revolt," Reviews in American History 13 (1985), 142. The book earned Hicks his post at Wisconsin. Hicks recalled that Carl Russell Fish began his search for a replacement for Paxson "by removing my book, The Populist Revolt, from the office shelf, and taking it home with him. In a matter of days he wrote me what he chose to call 'a love letter,' inviting me to join the Wisconsin staff." Hicks, "My Ten Years on the Wisconsin Faculty," 305.

103. Merk to Hicks, 2/10/1932, Hicks Papers.

104. Smith, "Frederick Merk and the Frontier Experience," 144. Merk's later Agricultural History Society presidential address focused on developments in the East that contributed to agrarian unrest in the West. Frederick Merk, "Eastern Antecedents of the Grangers," Ag History 23 (1949), 1-8. 
Hicks claimed, Saloutos largely wrote the resulting book with himself as "silent partner in the enterprise." 105

TO STUDY POPULISM is to study farming, and the Prairie Historians, many of them products of midwestern farms, were intense about this enterprise. The midwestern democracy that Turner chronicled had its "economic basis," Barnhart noted, in the small farm; thus Turner actively promoted the study of agricultural history. ${ }^{106}$ Malin thought that Turner's frontier thesis was essentially an "agricultural interpretation of American history." 107 The Prairie Historians followed this course of study by actively promoting the creation of the Agricultural History Society in 1919, which, like the MVHA, was also resisted by the AHA. ${ }^{108}$ Supporting and advocating the study of farming was a natural fit for historians focused on the Midwest. ${ }^{109}$ In 1934 Iowa State University historian Louis Bernard Schmidt, born in Belle Plaine, Iowa, gave his presidential address to the Agricultural History Society that underscored the centrality of family farming to the region. ${ }^{110}$ An "ardent admirer" of Turner and a proud "son of the Middle Border," Schmidt explained the development of farming in the prairie Midwest and the distribution of land that had created 6.5 million farms in the region by 1920.111 The prairies, he noted, generated over 60 percent of the nation's farm

105. Hicks, "My Ten Years on the Wisconsin Faculty," 309. See Theodore Saloutos and John D. Hicks, Agricultural Discontent in the Middle West, 1900-1939 (Madison, WI, 1951).

106. Barnhart, Valley of Democracy, 8; Nettels, "History Out of Wisconsin," 118.

107. James C. Malin, "Mobility and History: Reflections on the Agricultural Policies of the United States in Relation to a Mechanized World," Ag History 17 (1943), 177.

108. Novick, That Noble Dream, 182.

119. Pelzer et al., "Projects in American History and Culture," 507.

110. Schmidt was head of the Department of History and Government at Iowa State (1919-1945) and "pioneered courses in agricultural history and farmers' movements." W. Turrentine Jackson, "A Dedication to the Memory of Louis Bernard Schmidt, 1879-1963," Arizona and the West 15 (1973), 103-4. See also Louis Bernard Schmidt, "The Economic History of American Agriculture as a Field for Study," MVHR 3 (1916), 39-50; and idem, "The Role and Techniques of Agrarian Pressure Groups," Ag History 30 (1956), 49-58.

111. Louis Bernard Schmidt, "The Agricultural Revolution in the Prairies and the Great Plains of the United States," Ag History 8 (1934), 173. 
income and gave the nation its secretaries of agriculture. ${ }^{112}$ Several Prairie Historians were active in and served as president of the Agricultural History Society and published articles in and served as editors for its journal, Agricultural History. Agricultural history courses were common at land-grant institutions in the Midwest, and those institutions themselves were studied and held in high regard by the Prairie Historians. ${ }^{113}$ When he died, Paxson was working on a history of land-grant universities. He was half finished with the book when he told administrators he could not finish, left his study, went to the hospital, and died.114

The agricultural history genre included Allan Bogue's classic treatment of midwestern farming, From Prairie to Corn Belt.115 Bogue was raised on a farm in Ontario. ${ }^{116}$ When he was considering graduate school, he wrote to the president of the Agricultural History Society and asked for advice on where to study. Bogue decided to study at Cornell with Merk's student Paul Gates, who introduced Bogue to Malin, whom Bogue thanked for his help with From Prairie to Corn Belt.117 Revealing his own

112. From 1889, when the post was given cabinet rank, until the 1930s, the U.S. Secretary of Agriculture was always from the prairies or Great Plains. Louis Bernard Schmidt, "The Agricultural Revolution in the Prairies and the Great Plains of the United States," Ag History 8 (1934), 181, 184.

113. Merle Curti and Vernon Carstensen, The University of Wisconsin: A History, 1848-1925, 2 vols. (Madison, WI, 1949); Carstensen, "The Origin and Early Development of the Wisconsin Idea," Wisconsin Magazine of History 39 (1956), 181-88; Earle D. Ross, Democracy's College: The Land-Grant Movement in the Formative Stage (Ames, 1942); Schmidt, "The Agricultural Revolution in the Prairies and the Great Plains," 181-82. David Smith, in "Frederick Merk and the Frontier Experience," 142, said that Merk "embodied" the ideal that Justin Morrill envisioned for land-grant colleges.

114. Clark, "Frederic Logan Paxson," 108; Hicks, "Historical News and Comments," 373; Earl Pomeroy, "Frederic L. Paxson and His Approach to History," MVHR 39 (1953), 690.

115. Allan G. Bogue, From Prairie to Corn Belt: Farming on the Illinois and Iowa Prairies in the Nineteenth Century (Chicago, 1963).

116. Bogue recently said, "I was born a midwesterner because southwestern Ontario is essentially midwestern in its natural environment-farther west than Ohio, farther south than much of Minnesota and Wisconsin." Bogue, interview with author, 5/7/2007; Bogue, "Tilling Agricultural History with Paul Wallace Gates and James C. Malin," 438. See also Bogue, The Farm on North Talbot Road (Lincoln, NE, 2001), xii.

117. Bogue also met his future wife, Margaret Beattie Bogue, in Gates's seminar. About the time Allan published From Prairie to Corn Belt, Margaret published 
agrarian roots, Bogue argued that such works of history were needed because "city-reared and urban-oriented historians [had] come increasingly to dominate our profession." 118 Bogue chronicled the agrarian settlement of the Iowa and Illinois prairie and sought to focus on "the man with dirt on his hands and dung on his boots." 119 He discussed the settlers' reaction to the prairie experience, where they settled, how they acquired land, where they were from in the states to the east and in Europe, how they built houses and barns, how they plowed, raised livestock, used machinery, and innovated, how they consumed farm newspapers and attended agricultural fairs, and how they dealt with the costs of farming such as credit, taxes, and shipping. Bogue concluded that the "achievements had been striking" for the prairie farmer and that by the end of the nineteenth century the farmer could look back and think it "was good to have pioneered here, to have been an 'old settler,' and made virgin prairie 'productive' by stocking it with fine animals and raising bountiful crops." 120

Bogue thought that prairie farmers had a "strong commercial orientation." Along with other Prairie Historians, he devoted significant attention to the brass tacks of farm economics. His first book, which began as a dissertation under Gates and was made possible by time he spent studying with Malin in Kansas, examined the intricacies of farm mortgages in the Midwest. ${ }^{121}$ Bogue's work followed in a tradition that traced back to Turner, who emphasized economic history, as did subsequent Prairie

Patterns from the Sod: Land Use and Tenure in the Grand Prairie, 1850-1900 (Springfield, IL, 1959).

118. Bogue, From Prairie to Corn Belt, preface. Gates was the reader for the book's publisher. Bogue thanked Malin for his comments on the book and expressed "shock" at the negative review of the book in the MVHR by Mary Hargreaves, who had been a student of Gates (when he taught at Bucknell) and Merk (in graduate school at Harvard). Bogue to Malin, 7/13/1964, Malin Papers.

119. Bogue, From Prairie to Corn Belt, 1 . Bogue said, "Iowa is virgin territory almost for quantitative analysis on the pioneer process." Bogue to Malin, 1/10/ 1954, Malin Papers.

120. Bogue, From Prairie to Corn Belt, 287.

121. Allan G. Bogue, Money at Interest: The Farm Mortgage on the Middle Border (Lincoln, NE, 1955). Bogue said that Ray Allen Billington's treatment of western mortgages made his survey textbook, Westward Expansion (New York, 1949), a "damn waste of paper and money." Bogue to Malin, 3/19/1950, Malin Papers. 
Historians. ${ }^{122}$ Bogue and other Prairie Historians expanded on this tradition of economic history by promoting the broader use of statistical and quantitative methods. ${ }^{123}$ Bogue said that statistics were "like drug addiction. I realize that I am hooked, regret it periodically, but keep coming back." 124 Beyond economics and statistics, Bogue more generally advocated that historians use insights from the social sciences. ${ }^{125}$

WHEN STUDYING the economic details of agriculture and the broader story of midwestern farming, the Prairie Historians closely examined land distribution and geography. Bogue's mentor Paul Gates, who devoted the bulk of his career to studying land distribution, believed that no other issue so consumed the federal government in the century after the Revolution. ${ }^{126}$

122. Jensen, “On Modernizing Frederick Jackson Turner," 317; Gerald D. Nash, "John D. Hicks," in Wunder, ed., Historians of the American Frontier, 308. While at the Wisconsin Historical Society, Merk wrote Economic History of Wisconsin during the Civil War Decade (Madison, WI, 1916), which Harvard accepted as his dissertation. Paul, "Frederick Merk, Teacher and Scholar," 140. The famous business historian Alfred Chandler was a student of Merk. Blum, "A Celebration of Frederick Merk, 1887-1977." Turner's focus on economic history and the work of his "historical followers, helped to lay the groundwork for the more aggressive use of the economic interpretation of history that came with Beard's generation." Richard Hofstadter, The Progressive Historians: Turner, Beard, Parrington (New York, 1968), 72.

123. Bogue to Malin, 3/19/1959 and 2/11/1971, Malin Papers; E. David Cronon, "Merle Curti: An Appraisal and Bibliography of his Writings," Wisconsin Magazine of History 54 (1970-71), 121; Wilkins, “Orin G. Libby, 1864-1952," 110; Smith, "Frederick Merk and the Frontier Experience," 143.

124. Bogue to Malin, 8/14/1968, Malin Papers; Allan G. Bogue, "The Quest for Numeracy: Data and Methods in American Political History," Journal of Interdisciplinary History 21 (1990), 89-116. See also the work of Bogue's student Robert Swierenga, "Computers and American History: The Impact of the 'New' Generation," JAH 60 (1974), 1045-70; and William Silag, "Pioneers in Quantitative History at the University of Iowa," Annals of Iowa 46 (1981), 121-34.

125. Allan G. Bogue, "Social Theory and the Pioneer," Ag History 34 (1960), 34; Nash, Creating the West, 69.

126. Thomas C. McClintock, "Frederick Merk," in Wunder, ed., Historians of the American Frontier, 435; Margaret Beattie Bogue and Allan G. Bogue, "Paul W. Gates," Great Plains Journal 19 (1979), 22; Paul Gates, The Farmers' Age: Agriculture, 1815-1860 (New York, 1960), 51; idem, "The Homestead Law in an Incongruous Land System," AHR 41 (1936), 652-81; idem, "The Role of the Land Speculator in Western Development," Pennsylvania Magazine of History and Biography 66 (1942), 314-33; idem, Frontier Landlords and Pioneer Tenants (Ithaca, 
Merk thought that Gates, through his "intensive borings in manuscript collections," was the scholar who had "most effectively modified the Turner hypothesis" by explaining how the distribution of land had been disrupted by speculators. But Merk also thought that Gates had "pushed his ideas rather hard."127 Merk, Paxson, and Vernon Carstensen all wrote extensively and often critically about federal land policy, and the Prairie Historians called for others to study land policies as well. ${ }^{128}$

In tandem with their studies of land distribution, Turner and the Prairie Historians all took geography and the role of environmental conditions in the settlement process seriously. ${ }^{129}$ In the 1890s Turner had called for the study of the "physiographic basis" of American history and for the historian to work "hand in hand" with "the geologist, the meteorologist, the biologist." 130 The Prairie Historians followed these suggestions and discussed

NY, 1945). For a survey of work on this topic, see idem, "Research in the History of the Public Lands," Ag History 48 (1974), 31-50. For a survey of Gates's work, see Harry N. Scheiber, "The Economic Historian as Realist and as Keeper of Democratic Ideals: Paul Wallace Gates's Studies of American Land Policy," Journal of Economic History 40 (1980), 585-93; and Frederick Merk, "Foreword," in David M. Ellis, ed., The Frontier in American Development: Essays in Honor of Paul Wallace Gates (Ithaca, NY, 1969), ix-xxx.

127. Frederick Merk to Merle Curti, 12/15/1949, folder 1, box 26, Curti Papers; Merk to Gates, 9/11/1935, Gates Papers.

128. Buck, "The Progress and Possibilities of Mississippi Valley History," 8; Pelzer et al., "Projects in American History and Culture," 504-6; Frederick Merk, History of the Westward Movement (New York, 1978), 605; Smith, "Frederick Merk and the Frontier Experience," 143; Paxson, History of the American Frontier, 43-70; Vernon Carstensen, ed., The Public Lands: Studies in the History of the Public Domain (Madison, WI, 1963). Carstensen's students include University of Iowa historian Malcolm Rohrbough, whose first book was The Land Office Business: The Settlement and Administration of American Public Lands, 17891837 (New York, 1968); and Richard White, whose first book was Land Use, Environment, and Social Change: The Shaping of Island County, Washington (Seattle, 1979).

129. Bogue, Frederick Jackson Turner, 239-42, 430; Everett E. Edwards, "Middle Western Agricultural History as a Field of Research," MVHR 24 (1937), 317-18; Steiner, "The Significance of Turner's Sectional Thesis," 451, 454; Jensen, "On Modernizing Frederick Jackson Turner," 308; Libby, "Some Aspects of MidWest America," 213; Smith, "Frederick Merk and the Frontier Experience," 143; Elmer Ellis, “Louis Pelzer: Scholar, Teacher, Editor," MVHR 33 (1946), 209.

130. Steiner, "The Significance of Turner's Sectional Thesis," 451, 454 (quoting Turner); Jensen, “On Modernizing Frederick Jackson Turner,” 308. 
soils, grasses, and geographic formations extensively. ${ }^{131}$ Malin was particularly interested in what would now be considered environmental history, asking "How much has man modified the ecological setting of history in America?"132 Malin focused on linking ecology and the natural sciences to historical development. Merk told Malin that he had a "genius for tying in the sciences, and especially the more rapidly developing sciences, with history." "No other American historian," he said, "writes as you do the insights of science and history." 133 After reading Malin's Grassland of North America, Merk responded that he had "not often in recent years read a work as filled as this with new information, ideas, and approaches." The book, he said, "represents a new plateau in our knowledge of western America which historians of the future will have to ascend before they begin their own work." 134

Hicks wished he knew as much about agriculture as Malin and said that Malin's work was "as important as anything that is going on in the historical world." Bogue also praised Malin's work and applied his insights in his own research. Turner's and Malin's differing forms of emphasis on the role of the natural environment shaped the work of the Prairie Historians. In an address to the Agricultural History Society a few weeks after Pearl Harbor, for example, Everett Dick set forth a broad range of environmental adaptations and developments that frontier farmers endured and promoted, much as he did in several books. Vernon Carstensen continued that focus. Richard White noted that Carstensen went beyond "farms and farming" and

131. Merk to Malin, 1/27/1947 and 11/18/1947, and Hicks to Malin, 2/7/1942, Malin Papers; Gates, The Farmers' Age, 180; Pelzer et al., "Projects in American History and Culture," 506-7; Edwards, "Middle Western Agricultural History as a Field of Research," 317-18.

132. James Malin, "Ecology and History," Scientific Monthly 70 (May 1950), 297. Blegen also helped to found the Forest History Society. Tyrrell, "Public at the Creation," 40. Malin, who thought that there had been "less fundamental change than is usually assumed by conservation propagandists," resisted, along with Merk and Bogue, what he considered the misuse of environmental data to promote natural resource policies during the New Deal era. Malin, "Ecology and History," 297; Malin, "Space and History," part 2, 120; Merk to Malin, 1/27/1947 and 5/6/1947, and Bogue to Malin, 2/11/1956 and 3/11/1956, Malin Papers.

133. Merk to Malin, 5/6/1947 and 3/15/1952, Malin Papers.

134. Merk to Malin, 11/18/1947, Malin Papers. 
remained "endlessly fascinated by how the natural world responded to human attempts to control it and by the odd results those attempts sometimes yielded." 135

THE WORK OF MALIN, who emphasized the importance of writing history from the "bottom up," also underscores the Prairie Historians' attention to early forms of social history. ${ }^{136}$ In keeping with a focus on frontier democracy, farming, and economic history, however, there was naturally a political and economic spine to the corpus of works produced by the Prairie Historians. Paxson said he "found the political framework, among other conventional frameworks, indispensible in telling a general story," as did Pease. ${ }^{137}$ Hicks taught "American Social History" at Wisconsin and tried to squeeze out all mentions of "political and economic" factors, but agreed with Paxson that it was like "trying to nail jelly to the wall." Hicks said that "political and economic history weave together readily and provide an almost essential background for every other kind of history." Without them, a "reliable scheme of organization is hard to find." Hicks tried to organize the course around "cross sections of American life and thought," but thought this only worked if the "students already knew their political and economic history." 138

Despite these obstacles, the Prairie Historians were keen to examine social history, again following Turner, who first revolted against a history profession focused solely on the East, elites, and formal politics and diplomacy. ${ }^{139}$ Michael Steiner

135. Hicks to Malin, 5/15/1944, and Bogue to Malin, 11/2/1947, 6/7/1963, and 11/26/1950, Malin Papers; Everett Dick, "Going Beyond the Ninety-fifth Meridian," Ag History 17 (1943), 105; Richard White, "Obituary," WHQ 24 (1993), 138; Richard White, interview with author, 7/27/2011. See also Karl Brooks, "The Wild One: Environmental History as Redheaded Stepchild," in Kirkendall, ed., The OAH, 212.

136. Malin, “On the Nature of Local History," 228.

137. Howard R. Lamar, "Earl Pomeroy, Historian's Historian," Pacific Historical Review 56 (1987), 551; Pease, The Frontier State.

138. Hicks, "My Ten Years on the Wisconsin Faculty," 306.

139. Fulmer Mood, "The Theory of the History of an American Section in the Practice of R. Carlyle Buley," 4, noted that before Turner most historians focused on "political and institutional history" but that Turner promoted economic and "social history." 
calls Turner "perhaps our first self-conscious social historian." 140 Alvord, Pease, Buck, Pelzer, Paxson, Merk, Gates, Blegen, Buley, and Dick followed suit and all advocated and wrote social history. ${ }^{141}$ Alvord called for a "real history" that went beyond governors' messages and treasury accountings and that exhibited a "far greater knowledge of the life of the people." 142 Pelzer was seen as "primarily a social historian" because he was "interested in people, in what they thought and did and how they lived" and focused on their "social customs and manners." 143 Blegen condemned the "arrogance" and narrowness of eliteoriented history, which "masked an ignorance of, and disinterest in, the actualities of the common life."144 Everett Dick's books about the settlement of the prairie and plains were thick with the details of social history. ${ }^{145}$ Carlyle Buley's massive twovolume treatment of early life in the Midwest, which won the

140. Steiner, "Frontier to Region," 490; Hofstadter, The Progressive Historians, 72.

141. Louis Pelzer, "History Made by Plain Men," Iowa Journal of History and Politics 11 (1913), 307-22; Pelzer et al., "Projects in American History and Culture," 517; Pease, The Frontier State, 20-23; Buck, "The Progress and Possibilities of Mississippi Valley History," 6-10; Smith, "Frederick Merk and the Frontier Experience," 143; R. Carlyle Buley, "Glimpses of Pioneer Mid-west Social and Cultural History," MVHR 23 (1937), 481-510; idem, The Old Northwest, 1:138239; Buley to Stanley Pargellis, 8/15/1944, Carlyle Buley Papers; Herbert A. Kellar, "Louis Pelzer: Scholar, Teacher, Editor," MVHR 33 (1946), 204; Alvord, "The Relation of the State to Historical Work," 8, 15; Paxson, History of the American Frontier, 113; Fred A. Shannon, "The Life of the Common Soldier in the Union Army, 1861-1865," MVHR 13 (1927), 465-82; Joseph Schafer, "The Wisconsin Domesday Book," Wisconsin Magazine of History 4 (1920), 61-74; Stephanie J. Shaw, "The Long and Influential Life of Social History in the MVHR and the JAH," in Kirkendall, ed., The OAH, 127-32.

142. Alvord, "The Relation of the State to Historical Work," 8, 15.

143. Kellar, “Louis Pelzer," 204; Philip D. Jordan, “Louis Pelzer: Scholar, Teacher, Editor," MVHR 33 (1946), 215.

144. Blegen, Grassroots History, 6, 15.

145. Everett Dick, The Sod-House Frontier: A Social History of the Northern Plains from the Creation of Kansas and Nebraska to the Admission of the Dakotas (Lincoln, NE, 1954); idem, Vanguards of the Frontier: A Social History of the Northern Plains and Rocky Mountains from the Earliest White Contacts to the Coming of the Homemaker (New York, 1941); idem, The Lure of the Land: A Social History of the Public Lands from the Articles of Confederation to the New Deal (Lincoln, NE, 1970). In 1952 a survey of historians indicated that The Sod-House Frontier was among the top 15 books published between 1936 and 1950. Gilbert C. Fite, "Everett Dick," Great Plains Journal 19 (1979), 17, 21. 


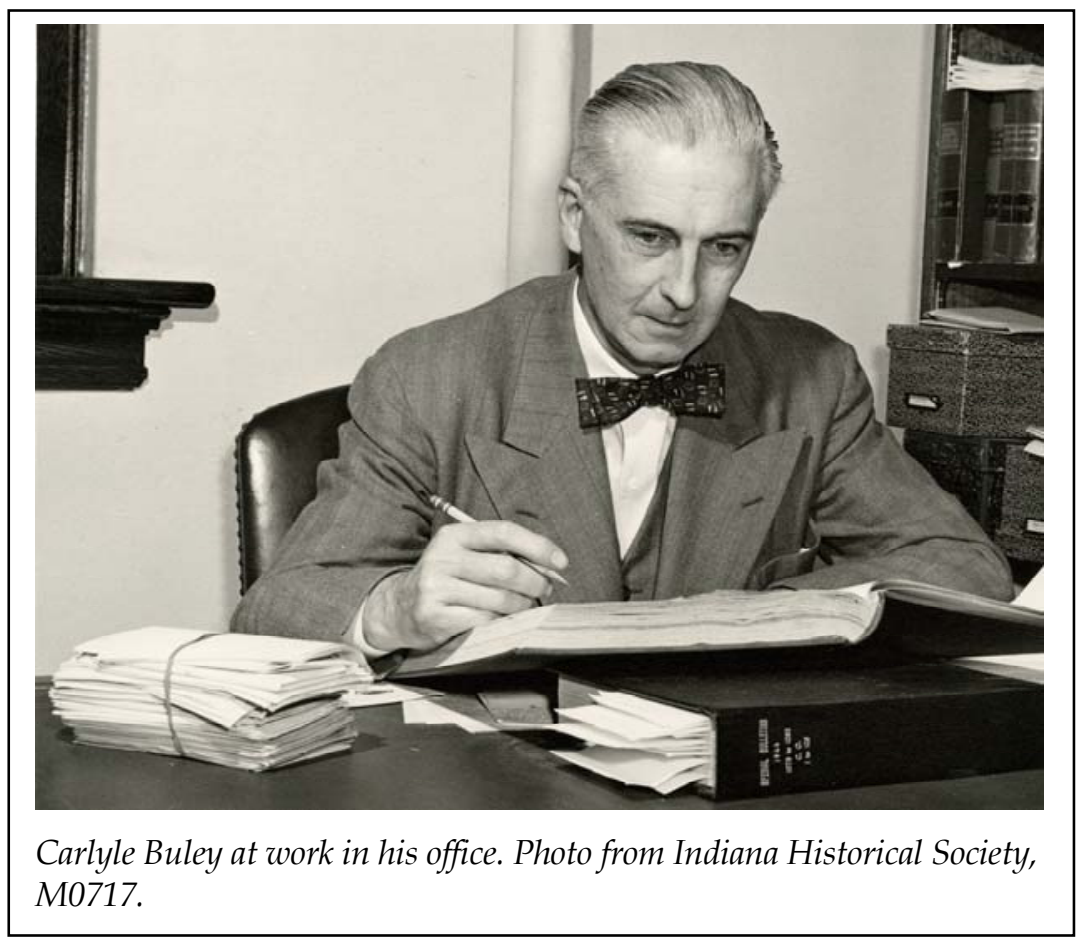

Pulitzer Prize in 1951, was also replete with the details of social life. The book was so massively detailed and lengthy that Buley struggled for years to find a publisher. A son of Indiana who had studied with Turner, Paxson, and Schafer and earned his Ph.D. from Wisconsin, Buley had taught midwestern history for decades at Indiana, and his book, which he had been planning since 1923, represented the culmination of much of the work of the Prairie Historians. He joked that he probably won the Pulitzer because "there was some midwesterner on the committee." 146

IF A SYMPATHETIC MIDWESTERNER on the Pulitzer committee gave Buley a boost, it would have been part of a strong midwestern regionalist sentiment that united the Prairie Historians during the early decades of the twentieth century.

146. Buley to Charles D. Anderson, 8/20/1947; Rosemary B. York to Buley, 5/6/1948; Arthur W. Wang to Buley, 7/7/1948; Edward C. Aswell to Buley, 8/16/1948; Buley to Stanley Pargellis, 8/15/1944; and Buley to Philip D. Jordan, 5/24/1951, all in Buley Papers. 
The Prairie Historians brought to the study of history personal experiences, often on farms or in small towns in the Midwest, that shaped their views and provided a regionalist ethos that unified their work. In their revolt against eastern condescension and neglect, the Prairie Historians gave birth to an intellectual movement organized around the study of the democratic, economic, and social development of the Midwest that was supported by regional research institutions and scholarly journals. While maintaining scholarly norms, they also understood that by compensating for eastern historians' ignorance of the "great interior of North America" they could, as Libby said, generate histories from an "altogether different viewpoint." 147

In the course of their work, the Prairie Historians sought to maintain their movement's regional grounding. When deciding on meeting locations for the MVHA, they sought out "different points in the west" and were guided by the principle of "locality." 148 When seeking a new director for the Wisconsin Historical Society, they praised a candidate for completing research "in the Middle Western field," rejected one for his "lack of a western connection," and ruled out a southerner because of "his lack of experience with Middle Western mores and his lack of knowledge of Middle Western history." 149 They praised the University of Minnesota for providing fellowships for regional writers and the University of Minnesota Press for making a "place, and a large place, for books interpreting the Upper Midwest."150 In a measure of the Prairie Historians' regional consciousness, Bogue rejected the idea of living in the urban East, and Hicks turned down an offer from Harvard because he said he "could never fit comfortably into an Eastern environment."151 Some

147. Libby, “The New Northwest,” 345-46.

148. Alvord to Clarence Paine, 6/24/1914, and unknown to Clarence Paine, 9/28/1914, MVHA correspondence, vol. 1, Alvord Papers.

149. Buck to Hicks, 3/5/1941; Hicks to Buck, 4/23/1941; and Buck to Hicks, 4/21/1941, box 8, Solon Buck Papers.

150. Blegen, Grassroots History, 11.

151. Bogue to Malin, 8/10/1971, Malin Papers; Hicks, "My Ten Years on the Wisconsin Faculty," 315. When Merk left the Wisconsin Historical Society to continue his studies at Harvard, Milo Quaife worried that he might become "an effete Easterner." Quaife to Merk, 10/5/1916, General Administrative Correspondence of WHS, 1900-2000, Wisconsin Historical Society, Madison, WI. 
devotees of the midwestern cause resented Turner for "deserting the West" and moving to Harvard, but he insisted, "I am still a western man in all but my place of residence." 152 These commitments were part of the persisting belief that professors "should be spiritually attuned to the region" where they worked and should contribute to the "continued regionalism" within the American historical profession during the early twentieth century. ${ }^{153}$

In subsequent decades younger generations of historians have moved in different directions, and the midwestern impulse in historical writing has lost the force it once enjoyed. In a move that symbolized that decline and the withering of regional attachments, in the 1960s the Prairie Historians' old organ, the $M V H R$, became the more general Journal of American History. ${ }^{154}$ But even at this distant remove, the Prairie Historians deserve to be remembered for what they accomplished and for the trends they anticipated. When Carlyle Buley was researching an earlier group of midwestern historians, he noted that they had been "more or less forgotten, unknown to any except specialists in the field," but that they were "too important to be permitted to pass into oblivion." 155 So, too, are the Prairie Historians, who called attention to the Midwest, toiled to make the region's historical institutions functional and productive, wrote substantial histories of the region, won Pulitzer Prizes, and focused on our democratic heritage and prospects, points of emphasis that can help us all.

152. Hofstadter, The Progressive Historians, 79-80.

153. Novick, That Noble Dream, 180-81, 185.

154. James Madison notes that without a topically oriented journal "there can be no field, no sense of scholarly community around a subject, no us/them, no impetus to think of a genre of scholarship." Madison, "Diverging Trails: Why the Midwest is Not the West," in Robert C. Ritchie and Paul Andrew Hutton, eds., Frontier and Region: Essays in Honor of Martin Ridge (Albuquerque, NM, 1997), 43.

155. Buley to Stanley Pargellis, 8/15/1944, Buley Papers. 